\title{
Corporate Social Responsibility Reporting by Forest Companies: the Study of Forest-based Industry in China
}

\author{
Jia Li 1,a, \\ ${ }^{1}$ College of Economics and Management, Nanjing Forestry University, Longpan Road 159, 210037, \\ Nanjing, China \\ alijiashy@hotmail.com
}

Keywords: Corporate social responsibility; forest industry; corporate policy; sustainability disclosure; China.

\begin{abstract}
With growing public interest in and global consciousness of environmental and social issues, the availability of sustainability performance of forest-based companies link closely with ecological environment is recognized critically important in contemporary global business management, in particular with the ongoing globalization of forest industry and conflicting stakeholder pressure. Through analyzing the annual corporate social responsibility (CSR) policies and reports in Chinese forest industry, this study identified the current corporate responsibility reporting level of forest-based industry, and examined the report contents of important forest-based companies, to provide a better understanding of the sustainable disclosure of forest-based industry in China. Although the number and percentage of forest-based companies publishing CSR reports are increased gradually, the content of many CSR reports are still quite simple and not complete. Finally, some policy recommendations are suggested to enhance the CSR reporting incentives.
\end{abstract}

\section{Introduction}

Companies are considering the broad social and environmental implications of their activities, when the impacts of company operations on society and the natural environment have been drawing increasingly attention in academic and public. As the general public worldwide becomes more concerned about the environment, there is increasing demand for firms to disclose more information relevant to their performance in this area to demonstrate the extent to which they are fulfilling their environmental responsibilities. The interaction with natural environment and society of companies are often communicated in publicly available corporate social responsibility (CSR) reports, which is also regarding as a proactive strategy in the company management and communication with stakeholders groups.

This century, with the rapid economic development, global environment and resource are facing severe problems, while the function of forest industry gained great concerning in global sustainable development due to forest providing important economic and ecological value. Simultaneously, plenty of studies show that forest industry cause about water deficiency, loss of biodiversity, ecotoxicity, acidification, solid waste, consumption of raw material and emission to air, water and soil, as well as on ecosystems (Gabel et al., 1996, Koskela, 2011). The sustainable development of forest is becoming the critical issue of global ecological conservation, while the growing public interest in and global consciousness of environmental and social issues. Among highly environmentally sensitive sectors, the forest-based industry has a global significance, not only because of its unique raw material base associated with the global greenhouse gas balance, but also because of the ongoing globalization of industry and conflicting stakeholder pressure (Vidal and Kozak, 2008, Wilmshurst and Frost, 2000). Sustainability disclosure is particularly relevant for resource-based industries, such as the forest sector, while forest industry globalization is leading to growing pressure on fragile ecosystems in the Global South (Toppinen et al., 2010). When forest sector is being increasingly viewed as a partner in providing solutions to many social and environmental concerns, the value of ecosystem services that forests provide have made a strong 
proactive-business strategy case for the forest sector wherein socio-environmental concerns (D'Amato et al., 2015).

Some literature are also discussed in the Chinese forest industry. The environmental accounting disclosure of forest listed companies in China are examined, and the result indicated the disclosure percentage is quite low and several suggestion such as improving environmental disclosure policies and strengthen the environmental accounting study (Liu et al., 2015). It is agreed that forest enterprises have specific social responsibility due to its industry or sector unique characteristics, it is significant for forest companies to implement and report corporate social responsibility in China (Gao, 2012; Jiang and Tian, 2011; Zhang and Sui, 2012), and sustainable management, emission reduction and increase carbon stock are suggested to realize the social responsibility (Yin et al., 2011). Through the content analysis of the CSR disclosure by forest listed companies in 2013, labor ranked highest in CSR disclosure following environmental information, but the samples were still quite limited(Li and Gao, 2015).

China is an important players in global forest product market, the globalization of forest industry drew great attention in Chinese forest companies' activities. Among environmentally sensitive sectors, the Chinese forest-based industry has a crucial role in global sustainable development, but is frequently under-represented in generic studies of corporate reporting, especially it is a lack of empirical studies exploring corporate sustainability disclosure. Hence very little is known about the current situation of CSR disclosure in forest-based industry, and what the companies report to the stakeholder in the communication of CSR with the public is still not clear. First, a review on CSR policy and development of forest-based sector in global and Chinese context will be provided. Next We will look closely at the CSR report of forest companies. This study aimed to provided a better understanding of the CSR reporting in Chinese forest industry by exploring topical area that companies have reported on, and draw policy implication for enhancing the responsibility activity and reporting.

\section{CSR Development in the Forest Industry}

2.1The CSR Development of Global Forest Industry Global Reporting Initiative (GRI) is the best-known framework for voluntary reporting of environmental and social performance by business and other organizations worldwide (Brown et al., 2009). While social reporting and the associated language, concepts and assumptions, have rapidly become a taken for granted practice for large corporations and GRI has played a dominant role, GRI has beeing a tool for managing sustainability and strengthening CSR by companies through private regulation and sustainability management practices (Brown et al., 2009, Hahn and Kühnen, 2013). The GRI framework provides extensive measures and occurrences for report content, which commitment to eleven reporting principles: transparency, inclusiveness, audit ability, clarity, completeness, relevance, sustainability context, accuracy, neutrality, comparability, clarity and timeliness (Li et al., 2011).

The International Organization for Standardization is a certificate organization defines environmental performance as 'the results obtained by an organization with regard to its activities that interact with the environment'. In this view, environmental performance extends beyond simple product-related environmental certificates to the adoption of environmental management practices and sustainable supply chain management (Raty et al.,2014). The International Organization for Standardization standard for environmental management systems (ISO 14001) is also applicable to forest management. With the support of environmental management system, CSR has typically been institutionalized through development and implementation of environmental and social standards such as codes of conduct (Luning, 2012).

2.2The CSR Development of Chinese Forest Industry The element of social responsibility has been introduced in China within the Company Law implemented in 2006. In the same year, the Shenzhen Stock Exchange Publish "Listed company social responsibility guideline" encouraging listed company fulfill social responsibility and reporting social responsibility information voluntarily. 
State-owned Assets Supervision and Administration Commission of the State Council published "The guideline about state-owned company exemplify social responsibility" which require state-owned company exemplify social responsibility actively. There is increasing demand on social responsibility from the public.

In 2007, the State Environmental Protection Administration (SEPA, renamed to Ministry of Environmental Protection in 2008) published "Environmental information disclosure method (to be implemented)". In February 2008, SEPA published "Instruction of strengthening supervision and management of environmental protection for listed companies" in order to promote the environmental administration and management in listed company. After that, Shanghai Stock Exchange published a regulation on "Strengthen the Corporate Responsibility activities undertaken by Listed companies" in order to promote and encourage the listed company to bear their social responsibility and report their CSR activities. At the same time, Shanghai Stock Exchange published the "Guide for listed company to have environmental information disclosure in Shanghai stock market" on account of the policies from SEPA. It was the initiation of CSR report, and some companies published environmental report instead. Although the disclosure is voluntary, more and more companies are publishing CSR Reports. In 2014, there are around 681 listed companies published CSR reports or Sustainable Reports, which increased 5.7\% according to 2013.

The Chinese Academy of Social Sciences published "Guide to formulate Corporate Social Report for enterprises in China" in 2009, which is the first instrumental book on CSR report formulation and disclosure. And now the Guidebook is updated to the third version in 2014. This guidebook integrated the international standard and domestic social responsibility development and practices in attempt to formulate an authorized reporting approach and index. Simultaneously, the industry association also drew substantial work on the CSR reporting. The China Forest Industry Federation and China National Forest Product Industry Association (FPIA) published the industrial standard "The Guide on Corporate Social Responsibility Report formulation by Forest-based enterprises" in July 2011. FPIA have been holding a CSR release conference each year since 2012, to promote CSR attention and reporting.

The forest certificates are developing quickly in China. FSC issued the first FSC-CoC certificate in 1999, and establish the Chinese work team in 2007. The FSC certificate increased dramatically in China while there are much attentions from global society and consumers on forest products sustainability. Some branches of international enterprises and domestic influential companies considered the FSC certificate an important indicator framework of social responsibility and green development. Until now there are around 1.2 million hectare forest achieved FSC certificates and around 4000 companies have the certificates. Seven corporations' subordinate companies among the top ten in paper industry obtained the FSC certificate. Among the twenty three senior members corporation of FPIA, twelve corporations' subordinate companies obtained FSC certificate as well. China Forest Certification Council (CFCC) was established in 2001 and published forest management and chain of custody (CoC) certificate standard in 2007. CFCC applied the member of PEFC in 2010 and start to apply the mutual recognition agreement with PEFC. In 2014, CFCC and PEFC are officially mutual recognition agreement, which will contribute to the sustainable development in forest-based industry.

The focus of CSR in the forest-based industries in China represents the sustainable development in this sector after decades of environmental destruction. The incorporating CSR in forest-based industry is that it provides a framework for delivering sustainable development and addressing environmental, ecosystem service and community development. Corporate social reporting has remained predominantly a voluntary practice, with many of current governmental policies predisposed to the concealment of environmental information. More and more companies are providing environmental and social information in their reports. Most of them clarify these information in the corporate social responsibility or sustainable repots, and the outlook on CSR reports development in forest-based industry will be clarified below 


\section{Materials and Methods}

The initial samples used in this study included the top 100 forest industry companies listed by FPIA, including top 30 in paper, wood-based panel, furniture industries and top 10 in other forest management companies. The CSR reports or sustainable reports from 2008 to 2015 are collected. The environmental reports which contained information dealing with social responsibility and stakeholders issues were also included. The Reports are collected from Listed companies information disclosure platform (CNINF website), the homepage of companies, and FPIA. However, there are only 6 reports found in 2015, because many companies will complete and publish their 2015 report later this year. As a result, we only calculate the disclosure level of CSR report from 2008 to 2014 in table 2 and 3. The analysis of these reports could provide an general overview on the current patterns of CSR reporting of forest-based company in China. A final sample of 47 forest companies met the criteria of this study.

\section{Results}

4.1Annual CSR Reports Number and Percentage The numbers of companies which have sustainable reports are increasing dramatically from 2 in 2008 to 33 in 2014. The first two years 2008 and 2009 are quite low as 2 and 5. In 2014 the number of reporting reached 33, which indicated some companies show their willingness in sustainable disclosure. Simultaneously, the number of listed companies increase from 2 to 18. The listed forest-based companies are categorized by standard classification rules by stock supervision team which include 45 listed companies. The percentages of the first two years 2008 and 2009 are quite lower as 4.4\%, 8.9\%. From 2008 to 2012, the percentages of reporting companies increased from less than 5 percent to around 40 percent which is around nine times over. In summary, most listed companies started sustainable disclosure from 2010, and then keep on around the level of $40 \%$.

This indicate that policy from Shanghai stock market requiring a corporate social report in 2008 drive the CSR reporting from listed company. However, after seven years development, the disclosure level is still less than 50 percent until now, and the number is almost stable from 2012 to 2014. This may relate to the CSR reporting policy is voluntary, hence the company can make their own decision. Moreover, this figure also shows that there still $60 \%$ potential in CSR reporting in forest-based listed companies, hence policy formulation attempt to encourage company to pay attention to their activities in CSR domain and report the relevant information to meet increasing demand on sustainable disclosure.

4.2The Character of Forest-based Companies and Their CSR Report Approaches In summary, the CSR report is formulated by company individually and FPIA. The development of CSR in China is promoted by the government and industry Association (FPIA). The companies who cooperate with FPIA in the CSR report formulation and publication is fluctuated. Specifically, the number of companies is 5 in the first year 2011, and then increase to 11 in 2012, after that it returned to 6 in 2013. And in 2014, besides the number reached 17, the forest association made a CSR white paper for the 17 companies together, within which each company has a section instead of a CSR report separately as the years before. Hence, the CSR content of each company in 2014 is simpler than the years before. The number of CSR report formulated by the company is quite lower as 2 in 2008, and the number increases to 18 in 2012, and almost stable in 2013 and 2014.

Companies choose to publish the CSR online and/or print outlets. In majority, the listed companies choose to publish the annual CSR report online. But some listed companies cooperate with FPIA in the formulation and publication of CSR report. These companies normally do not disclosure the CSR report online as the other companies cooperated with FPIA. Only one company Fenglin Group who put the CSR report in 2015 provided by the FPIA on its official website. Besides the companies cooperated with FPIA, the company Asian Paper and Pulp company also choose to print their CSR report instead of online release. 


\section{Conclusion}

The availability of sustainability performance of forest-based companies link closely with ecological environment is recognized critically important in contemporary global business management. CSR disclosure is also viewed as a commitment to transparency and as efforts to address social and environmental risks to meet the growing demand from different stakeholders in forest-based industry.

Through reviewing the CSR reporting development and polices in forest-based industries and examining the contents in CSR reports, this paper provided an analysis of those issues identified as influential to corporate management and the observed conditions of environmental disclosure within the annual reports. This study is providing a better understanding of the chronological development and characteristics of empirical research on sustainability-related reporting in forest-based industries since 2008 in term of empirical evidence, and the research provides important implications for CSR reporting practices and academic research.

While the stock exchange encourages listed firms to disclose CSR activities in CSR reports, the companies publishing their CSR report increased gradually to around 60\%, which still leave some space to improve. Although the number and percentage of forest-based companies are increased gradually, the content of most CSR reports are still quite simple and not complete. Some companies' CSR reports are even not continuing. While some companies are passive and only provided environmental information requested by regulations, other companies with an active environmental policy communicated about their overall eco-friendliness. Finally, the results also reveal a wide variation in the amount and format of CSR reporting among Chinese top companies, in particular has various specific sector variance.

These findings suggest that many corporate environmental disclosures were incomplete lacking of substantial important information. The reporting level is also comparable low given the present voluntary report schemes. It is critical therefore to exercise some practical measures to enhance the reporting incentives. The forest certification would be expected to be a stronger driver in considering the ecological impact and sustainability disclosure, in particular the mutual recognition of CFCC and PEFC. The promotion activity from FPIA which is also an important actor, could draw more attention on CSR reports from companies as well. The possible intervention and sufficient encouragement from the government may also enhance the CSR activities and reporting.

\section{References}

[1] H. S. Brown, M. de Jong, D. L. Levy, Building institutions based on information disclosure: lessons from GRI's sustainability reporting, Journal of Cleaner Production, vol. 17, pp. 571-580, 2009.

[2] D. D’Amato, N. Li, M. Rekola, A. Toppinen, F.F. Lu, Linking forest ecosystem services to corporate sustainability disclosure: A conceptual analysis, Ecosystem Services, 14, pp. 170-178, 2015.

[3] H. L. Gabel, P. M. Weaver, J. M. Bloemhof-Ruwaard, L. N. VanWassenhove, Lifecycle analysis and policy options: the case of the European pulp and paper industry, Business Strategy Environment, vol. 5, pp.156-167, 1996.

[4] E. Gao, Forestry Enterprise Multiple Social Responsibility Value and Its Realization of the Path, Forestry Economics, vol. 11, pp. 119-121, 2012 (in Chinese).

[5] R. Hahn, M. Kühnen, Determinants of sustainability reporting: a review of results, trends, theory, and opportunities in an expanding field of research, Journal of Cleaner Production, vol 59, pp. 5-21, 2013.

[6] M. Koskela, Expert views on environmental impacts and their measurement in the forest industry, Journal of Cleaner Production, vol. 1912, pp. 1365-1376, 2011. 
[7] D. Jiang, Z. Tian, Study on social responsibility about forestry enterprises in China, Forestry Economics, vol. 8, pp. 75-78, 2011 (in Chinese).

[8] N. Li, A. Toppinen, A. Tuppura, K. Puumalainen, M. Hujala, Determinants of Sustainability Disclosure in the Global Forest Industry. EJBO, vol. 16, pp. 33-40, 2011.

[9] Y. Li, L. Gao, Corporate social responsibility implementation in the forest sector: Contents, levels and the role of industries and resources, Forestry Economics, vol. 35, pp. 323-329, 2015 (in Chinese).

[10]M. Liu, Y. Li , Y. Wu, C. Zhang, Research on environmental accounting information disclosure of listed forestry companies in China. Issues in Agricultural Economy, vol. 1, pp. 66-72, 2015 (in Chinese).

[11]S. Luning, Corporate social responsibility (CSR) for exploration: consultants, companies and communities in processes of engagements. Resources Policy, vol. 37, pp. 205-211, 2012.

[12]A. Toppinen, N. Li, A. Tuppura, and Y. Xiong, Corporate Responsibility and Strategic Groups in the Forest-based Industry: Exploratory Analysis based on the Global Reporting Initiative (GRI) Framework. Corporate Social Responsibility Environment, vol. 19, pp. 191-205, 2012.

[13]N. G. Vidal, R. A Kozak, Corporate responsibility practices in the forestry sector: Definitions and the role of context, Journal of Corporate Citizenships, vol. 31, pp. 59-75, 2008.

[14]T. D. Wilmshurst, Frost, G.R. Corporate environmental reporting. Accounting, Auditing \&Accountability Journal, vol. 1, pp. 10-26, 2000.

[15]Z. Yin, , W. Song, , M. Tian, Thoughts on corporate social responsibility of forestry enterprises in China. World Forestry Research 2011, 8, 71-75 (in Chinese).

[16]W. Zhang, S. Sui, The Discussion of forestry corporation social responsibility in China, Forestry Economics, vol. 7, pp. 85-95, 2012 (in Chinese). 